\title{
ОСОБЕННОСТИ ТКАНЕВОЙ РЕАКЦИИ БРЮШНОЙ СТЕНКИ НА ИМПЛАНТАЦИЮ ЛЕГКОГО УСИЛЕННОГО ЭНДОПРОТЕЗА ДЛЯ ГЕРНИОПЛАСТИКИ В ЗАВИСИМОСТИ ОТ ВАРИАНТА ЕГО РАСПОЛОЖЕНИЯ
}

\author{
(С Суковатых Б.С. ${ }^{l}$, Блинков Ю.Ю. ${ }^{l}$, Нетяга А.А. ${ }^{2}$, Затолокина М.А. ${ }^{3}$, Полевой Ю.Ю. ${ }^{l}$, Жуковский В.А. ${ }^{4}$
}

${ }^{1}$ Кафедра общей хирургии, ${ }^{2}$ кафедра оперативной хирургии и топографической анатомии, ${ }^{3}$ кафедра гистологии, эмбриологии, цитологии Курского государственного медицинского университета, Курск; ${ }^{4}$ Общество с ограниченной ответственностью «Линтекс», Санкт-Петербург

E-mail: SukovatykhBS@,kursksmu.net

\begin{abstract}
Представлены результаты экспериментального исследования на кроликах породы шиншилла легкого усиленного эндопротеза при над- и подапоневротической имплантации в ткани брюшной стенки. Проведено морфологическое исследование образцов брюшной стенки с имплантированным материалом. Исследовали площадь клеточного инфильтрата, располагающегося непосредственно вокруг нитей эндопротеза в клеточном слое капсулы, и площадь вновь сформированной соединительнотканной капсулы, вычисляли клеточный индекс, представляющий собой отношение клеток гистиоцитарного ряда к клеткам воспалительного инфильтрата. В результате проведенного исследования установлено, что на ранних сроках более быстрое купирование воспалительных изменений и образование соединительнотканной капсулы отмечается вокруг эндопротеза при подапоневротической имплантации, а на поздних сроках течение репаративной реакции не зависит от варианта расположения протеза.
\end{abstract}

Ключевые слова: грыжа живота, легкий усиленный эндопротез, герниопластика, площадь клеточного инфильтрата, площадь соединительнотканной капсулы, клеточный индекс, полипропиленовый эндопротез.

\section{PECULIARITIES OF ABDOMINAL WALL TISSUE RESPONSE ON IMPLANTATION OF THE LIGHT STRENGTHENED ENDOPROSTHESIS FOR HERNIOPLASTY IN RELATION TO ITS ARRANGEMENT OPTION}

Sukovatykh B.S. ${ }^{1}$, Blinkov Yu.Yu. ${ }^{1}$, Netyaga A.A. ${ }^{2}$, Zatolokina M.A. ${ }^{3}$, Polevoy Yu.Yu. ${ }^{1}$, Zhukovskiy V.A. ${ }^{4}$

${ }^{1}$ Department of General Surgery, ${ }^{2}$ Department of Operative Surgery and Topographic Anatomy, ${ }^{3}$ Department of Histology, Embryology, Cytology of Kursk State Medical University, Kursk Limited Liability Company "Lintex", St. Petersburg

The article presents the results of experimental study of the light strengthened endoprosthesis on rabbits of chinchilla specie at onlay and sublay implantation in the abdominal wall tissues. There was done morphological study of abdominal tissue samples with implanted material. The area of cellular infiltrate located around the threads of endoprosthesis in cellular layer of the capsule, and area of newly formed connective tissue capsule were investigated. Cellular index was calculated as the ratio of the histiocytic cells to the inflammatory infiltrate cells. In the result of the study authors prove that at early periods the more rapid stopping of inflammatory changes and formation of the connective tissue capsule take place around endoprosthesis at sublay implanting, while at later periods reparative response does not depend on arrangement option of prosthesis.

Keywords: abdominal hernia, light strengthened endoprosthesis, hernioplasty, area of cellular infiltrate, area of connective tissue capsule, cellular index, polypropylene endoprosthesis.

Наибольшее распространение для герниопластики в абдоминальной хирургии получил стандартный полипропиленовый протез с диаметром нити 120 микрон. Данный протез имеет большую материалоемкость и жесткость, что вызывает ограничение подвижности брюшной стенки, хронический болевой синдром в области операционного рубца, ощущение у больных чувства «инородного тела» $[1,5]$. Для устранения описанных недостатков в клинической практике начали применяться легкие сетки с диаметром нити 90 микрон и суперлегкие с диаметром нити 70 микрон $[2,9]$. Недостатком этих сеток является низкая прочность изделия, которая при их имплантации в дефект апоневроза, превышающий $10 \mathrm{~cm}^{2}$ у больных с большими и гигантскими грыжами, может приводить к рецидиву заболевания [10, 11].

Для повышения прочности легких сеток в их структуру стали в заданном направлении вводить нити большего диаметра до 120 микрон. Фирмой «Линтекс» начал выпускаться отечественный легкий усиленный эндопротез «Флексилен», сочетающий высокую прочность с малой материалоемкостью. Однако биологические свойства этого протеза для герниопластики остаются малоизученными. Так, остаются не выявленными особенности тканевой реакции брюшной стенки при над (onlay) и под- (sablay) апоневротической имплантации легкого усиленного протеза. Как в России, так и за рубежом считается, что подапоневротическое расположение протеза с патогенетической точки зрения развития грыжи более оправдано, 
чем надапоневротическое [3, 8]. Однако подапоневротическая пластика более сложна в техническом исполнении, чем надапоневротическая, вследствие затруднения разделения слоев брюшной стенки в области грыжевых ворот из-за развития склеротических изменений при длительном существовании грыжи. Это требует больше времени для выполнения оперативного вмешательства, высокой квалификации хирурга. Кроме этого, при наличии воспалительного процесса в брюшной полости возможно инфицирование протеза [6]. Основными недостатками надапоневротической пластики являются отслойка подкожной клетчатки и кожи от апоневроза, что нарушает их кровоснабжение, венозный и лимфатический отток, способствует формированию сером и гнойных раневых осложнений [7].

Цель исследования: изучить особенности тканевой реакции брюшной стенки на имплантацию легкого усиленного полипропиленового протеза при над- и подапоневротическом расположении и на этой основе сформировать показания к вариантам его размещения.

\section{МАТЕРИАЛЫ И МЕТОДЫ ИССЛЕДОВАНИЯ}

Экспериментальные исследования были проведены на 60 кроликах породы шиншилла. В экспериментах были использованы кролики одного пола (женского) в возрасте 1-1,5 года, весом 2500-3500 г. Для исследования отбирались животные без внешних признаков заболевания, прошедшие карантин в условиях вивария. Все животные содержались в одинаковых условиях на стандартном пищевом режиме.

Для реализации цели исследования был использован новый легкий усиленный сетчатый полипропиленовый эндопротез «Флексилен», состоящий из горизонтально расположенных широких основных полос с диаметром нити 90 микрон и более узких усиленных полос с диаметром нити 120 микрон, ритмично чередующихся друг с другом.

Животные были разделены на 2 серии экспериментов по 30 особей в каждой. В 1-й серии имплантировали эндопротез в положении onlay, во 2-й - в положении sablay. Оперативные вмешательства выполнялись на кафедре оперативной хирургии и топографической анатомии Курского государственного медицинского университета. В обеих сериях эксперимента оперативные вмешательства были проведены в асептических условиях под общим наркозом с использование комбинации препаратов «Золетил 50» и «Ксила» («Рометар» (Rometar)). Первым этапом анестезиологического пособия являлось внутримышечное введение 2\% препарата «Ксила» в дозе 0,2 мл/кг массы животного в мышцы бедра. Следующим этапом, после предварительной подготовки места инъекции (удаление шерсти, обработка антисептиком), в ушную вену вводился препарат «Золетил 50» в дозе 5 мг/кг массы животного. Миорелаксация и анальгезия наступала через несколько секунд и продолжалась в течение 20-25 минут.

Оперативные вмешательства по методике onlay выполнялись следующим образом. По средней линии живота в продольном направлении рассекали кожу, подкожную клетчатку длинной 4-5 см. Белую линию живота и переднюю стенку влагалища (апоневроза) прямых мышц освобождали от клетчатки путем ее отсепаровки в стороны от срединного разреза, на расстояние 2,5-3 см. В созданное пространство помещали эндопротез размерами $3 \times 3$ см. Эндопротез размещали таким образом, чтобы его усиленные зоны располагались в поперечном к оси тела направлении, моделируя правила выполнения герниопластики этим материалом у пациентов с вентральными грыжами.

При подапоневротическом варианте расположения протеза по методике sublay по средней линии живота в продольном направлении рассекали кожу, подкожную клетчатку, апоневроз прямых мышц. Тупо и остро освобождали париетальную брюшину путем ее отсепаровки от задней стенки влагалища прямых мышц. В образовавшееся предбрюшинное пространство имплантировали полипропиленовый сетчатый эндопротез размерами $3 \times 3$ см. Как при над-, так и при подапоневротическом вариантах протезы фиксировали полипропиленовой нитью. Раны послойно ушивали, дренирование не производили.

Из эксперимента всех животных выводили путем передозировки средств для наркоза в соответствии с Конвенцией по защите животных, используемых в эксперименте и других научных целях, принятой Советом Европы в 1986 году на сроках 7, 30, 60, 90 и 180 суток.

После выведения животных из эксперимента в указанные сроки патоморфологические изменения тканей брюшной стенки оценивались макроскопически. Далее для гистологического исследования иссекали полнослойный лоскут передней брюшной стенки, включая исследуемый материал. Срезы, толщиной 7-8 мкм окрашивали гематоксилин-эозином и по Ван-Гизон.

Микроскопирование и микрофотосъемка осуществлялись с помощью оптической системы, состоящей из светового лабораторного микроскопа Levenhuk D320L. При гистологическом исследовании оценивали характер и выраженность патоморфологических изменений тканей, окружающих эндопротезы. При морфометрическом исследовании с помощью программы Levenhuk 
ToupView v.3.6.688 на малом увеличении (х100) исследовали площадь клеточного инфильтрата, располагающегося непосредственно вокруг нитей протеза, и площадь вновь сформированной соединительнотканной капсулы в квадратных микрометрах $\left(\right.$ мкм $\left.^{2}\right)$. На снимках, сделанных при большом увеличении (х400), исследовали количественный состав клеточных элементов (лимфоцитов, макрофагов, моноцитов, нейтрофилов, эозинофилов, фибробластов и фиброцитов), которые дифференцировали на основе кариологических признаков. Процентное соотношение указанных представителей клеточной популяции рассчитывали после подсчета 100 клеток в нескольких непересекающихся полях зрения на расстоянии 1-го поля зрения от нитей эндопротеза.

Для объективизации формирования заключения о характере течения раневого процесса вычисляли клеточный индекс по следующей формуле:

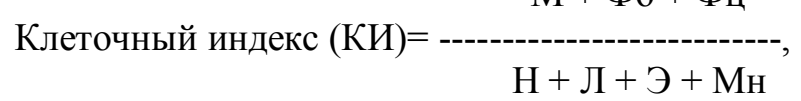

где М - макрофаги, Фб - фибробласты, Фц - фиброциты, Н - нейтрофилы, Л - лимфоциты, Э - эозинофилы, Мн - моноциты.

При значении клеточного индекса $<1$ делали вывод о преобладании воспалительных изменений, характерных для I фазы течения раневого процесса, при значении $>1$ делали вывод о преобладании репаративных тенденций, характерных для II фазы [4].

Полученные в результате представленных выше методик цифровые данные обрабатывались статистически с целью изучения значимости расхождений средних величин в сравниваемых группах. После определения типа распределения данных был выбран метод оценки достоверности отличий по критерию Вилкоксона-Манна-Уитни. Для подтверждения статистической гипотезы был выбран уровень значимости $\mathrm{p} \leq 0,05$, допустимый для экспериментальных медико-биологических исследований.

\section{РЕЗУЛЬТАТЫ ИССЛЕДОВАНИЯ И ИХ ОБСУЖДЕНИЕ}

Результаты морфометрического исследования клеточного состава и клеточного индекса на разные сроки эксперимента представлены в таблице 1.

Как при надапоневротическом, так и при подапоневротическом вариантах расположения протезов первая фаза раневого процесса была выражена в течение первых 7 суток от момента имплантации. Репаративные процессы при расположении протеза sublay преобладали над таковыми при расположении протеза onlay на 7-е сутки в 1,27 раза, на 30 -е сутки в 1,14 раза и на 60 -е сутки в 1,11 раза. На 90-е и 180-е сутки эксперимента различий показателей клеточного состава не было.

Количественная оценка клеточного состава свидетельствует о более раннем купировании воспалительных изменений и более высокой интенсивности репаративных процессов при подапоневротическом расположении протеза на ранних (до 60 суток) сроках эксперимента.

Таблица 1

Динамика морфометрических показателей в исследуемых сериях, $\mathrm{M} \pm \mathrm{m}$

\begin{tabular}{|l|c|c|c|c|c|c|}
\hline \multirow{2}{*}{ Показатели } & \multirow{2}{*}{$\begin{array}{c}\text { Серия } \\
\text { эксперимента }\end{array}$} & \multicolumn{5}{|c|}{ Сроки имплантации } \\
\cline { 3 - 7 } & 7 сут, $(\mathrm{n}=12)$ & $\begin{array}{c}30 \text { сут, } \\
(\mathrm{n}=12)\end{array}$ & $\begin{array}{c}60 \text { сут, } \\
(\mathrm{n}=12)\end{array}$ & $\begin{array}{c}90 \text { сут, } \\
(\mathrm{n}=12)\end{array}$ & $\begin{array}{c}180 \text { сут, } \\
(\mathrm{n}=12)\end{array}$ \\
\hline \multirow{2}{*}{ Нейтрофилы, \% } & 1-я onlay & $2,0 \pm 0,45^{*}$ & $0,33 \pm 0,21$ & - & - & - \\
\cline { 2 - 7 } & 2-я sublay & $0,83 \pm 0,40$ & - & - & - & - \\
\hline \multirow{2}{*}{ Лимфоциты, \% } & 1-я onlay & $29,33 \pm 0,88$ & $28,33 \pm 0,42$ & $25,50 \pm 0,76$ & $20,00 \pm 0,73$ & $16,83 \pm 0,48$ \\
\cline { 2 - 7 } & 2-я sublay & $29,67 \pm 0,61$ & $26,33 \pm 0,80$ & $23,83 \pm 0,48$ & $20,33 \pm 0,76$ & $16,50 \pm 0,43$ \\
\hline \multirow{2}{*}{ Эозинофилы, \% } & 1-я onlay & $12,67 \pm 1,15$ & $3,50 \pm 0,62$ & $2,50 \pm 0,43$ & $0,50 \pm 0,22$ & - \\
\cline { 2 - 7 } & 2-я sublay & $7,83 \pm 0,70^{*}$ & $3,17 \pm 0,31$ & $1,33 \pm 0,21$ & $0,50 \pm 0,22$ & - \\
\hline \multirow{2}{*}{ Моноциты, \% } & 1-я onlay & $13,17 \pm 0,48$ & $11,0 \pm 0,37$ & $7,50 \pm 0,43$ & $7,67 \pm 0,33$ & $6,67 \pm 0,42$ \\
\cline { 2 - 7 } & 2-я sublay & $12,50 \pm 0,72$ & $10,33 \pm 0,76$ & $8,00 \pm 0,26$ & $7,00 \pm 0,26$ & $7,00 \pm 037$ \\
\hline \multirow{2}{*}{ Макрофаги, \% } & 1-я onlay & $11,83 \pm 0,48$ & $12,50 \pm 0,56$ & $9,50 \pm 0,34$ & $9,17 \pm 0,60$ & $8,50 \pm 0,43$ \\
\cline { 2 - 7 } & 2-я sublay & $13,67 \pm 0,61$ & $12,00 \pm 0,93$ & $10,50 \pm 0,43$ & $10,00 \pm 0,52$ & $8,17 \pm 0,48$ \\
\hline \multirow{2}{*}{ Фибробласты, \% } & 1-я onlay & $29,17 \pm 1,01$ & $33,83 \pm 0,91$ & $35,67 \pm 0,76$ & $34,33 \pm 0,76$ & $33,50 \pm 0,43$ \\
\cline { 2 - 7 } & 2-я sublay & $32,50 \pm 0,56^{*}$ & $35,00 \pm 0,58$ & $35,33 \pm 0,42$ & $33,83 \pm 0,48$ & $33,17 \pm 0,54$ \\
\hline \multirow{2}{*}{ Фиброциты, \% } & 1-я onlay & $1,83 \pm 0,70$ & $10,50 \pm 1,18$ & $19,33 \pm 0,67$ & $28,33 \pm 0,56$ & $34,50 \pm 0,67$ \\
\cline { 2 - 7 } & 2-я sublay & $3,00 \pm 0,37$ & $13,17 \pm 1,33$ & $21,00 \pm 0,45$ & $28,00 \pm 0,58$ & $35,17 \pm 0,70$ \\
\hline \multirow{2}{*}{$\begin{array}{l}\text { Клеточный } \\
\text { индекс }\end{array}$} & 1-я onlay & $0,76 \pm 0,05$ & $1,32 \pm 0,02$ & $1,82 \pm 0,05$ & $2,56 \pm 0,06$ & $3,27 \pm 0,10$ \\
\cline { 2 - 7 } & 2-я sublay & $0,97 \pm 0,03^{*}$ & $1,51 \pm 0,03 *$ & $2,02 \pm 0,03 *$ & $2,59 \pm 0,07$ & $3,26 \pm 0,08$ \\
\hline
\end{tabular}

Примечание: * - различия показателей клеточного состава и клеточного индекса достоверны $(\mathrm{p} \leq 0,05)$ между 1-й и 2-й сериями. 
Динамика площадей инфильтратов и капсул (мкм $\left.{ }^{2}\right),(\mathrm{M} \pm \mathrm{m})$

\begin{tabular}{|c|c|c|c|}
\hline Срок наблюдения & 1-я серия оnlay $(\mathrm{n}=30)$ & 2-я серия sublay $(\mathrm{n}=30)$ & $\mathrm{p}$ \\
\hline \multicolumn{4}{|c|}{ Площадь инфильтрата } \\
\hline 7-е сутки & $22421 \pm 2315$ & $10459 \pm 972$ & $\leq 0,05$ \\
\hline 30-е сутки & $5158 \pm 327$ & $3499 \pm 214$ & $\leq 0,05$ \\
\hline \multicolumn{4}{|c|}{ Площадь капсулы } \\
\hline 30-е сутки & $427537 \pm 14985$ & $350533 \pm 20179$ & $\leq 0,05$ \\
\hline 60-е сутки & $554093 \pm 12469$ & $448015 \pm 12502$ & $\leq 0,05$ \\
\hline 90-е сутки & $578775 \pm 17354$ & $497183 \pm 16451$ & $\leq 0,05$ \\
\hline 180 -е сутки & $569977 \pm 25348$ & $500445 \pm 9076$ & $\leq 0,05$ \\
\hline
\end{tabular}

На поздних сроках (90-е и 180-е сутки) происходит выравнивание показателей клеточного состава капсул при обоих вариантах расположения протеза.

Это свидетельствует о том, что при любом расположении протеза с течением времени он в одинаковой степени становится биосовместимым с тканями реципиента.

Результаты морфометрического исследования площадей инфильтратов и капсул представлены в таблице 2.

С 7-х по 30-е сутки происходило уменьшение площадей инфильтратов в 4,3 в положении onlay, а в положении sublay в 3,0 раза. На 7-е сутки в первой серии площадь инфильтрата была в 2,1 раза, а на 30-е сутки в 1,47 раза больше, чем во второй серии. Вместе с этим начиная с $30-\mathrm{x}$ суток и до окончания эксперимента отмечалось увеличение площадей капсул в 1,33 раза в первой и в 1,43 раза во второй сериях. На 30 -е и 60 -е сутки данные показатели в первой серии были в 1,2 раза, на 90 -е сутки в 1,16 и 180 -е сутки в 1,4 раза больше, чем во второй серии.

Исследование площадей инфильтратов показало, что при надапоневротическом варианте расположения протеза данный показатель достоверно больше. Это может быть связано с техническими особенностями этого варианта, а именно с необходимостью пересечения большого количества кровеносных и лимфатических сосудов при отслойке кожи и подкожной клетчатки от апоневроза и, как следствие, с выходом клеточных элементов в ткани. В дальнейшем, начиная $\mathrm{c}$ 30-х суток, при надапоневротической имплантации отмечается достоверно выше площадь капсулы. С нашей точки зрения, это может быть обусловлено изначально большей площадью инфильтрации тканей.

При гистологическом изучении микропрепаратов установлено, что на 7-е сутки в положении onlay эндопротез окружен широкими полями незрелой соединительной ткани. Около нитей эндопротеза встречаются участки выраженной клеточной инфильтрации. Клетки воспалительного инфильтрата встречаются среди элементов молодой соединительной ткани на значительном расстоянии от эндопротеза. Среди клеток инфильтратов преобладают лимфоциты, макрофаги, эозинофилы и моноциты. Нейтрофильные лейкоциты единичные. В небольшом количестве встречаются молодые фибробласты. Вокруг нитей эндопротеза в положении sublay так же отмечается воспалительная инфильтрация. Клеточный состав инфильтратов аналогичен серии с имплантацией эндопротеза onlay. Однако в данном случае выявляется значительно большее количество фибробластов. Кроме этого, в некоторых наблюдениях встречаются участки с тонкой молодой соединительнотканной капсулой, незрелые слабооксифильные волокна которой в наружном слое приобретают упорядоченное и параллельное расположение друг другу.

На 30-е сутки вокруг нитей эндопротеза в положении onlay определяется волокнистая соединительнотканная капсула, состоящая из плотных коллагеновых волокон, отграничивающих эндопротез от окружающих тканей. Волокна капсулы без видимых границ переходят в окружающие ткани (рис. 1). Среди клеток наружного слоя капсулы присутствуют преимущественно фиброциты и фибробласты. Во внутренних отделах капсулы сохраняется круглоклеточная инфильтрация (рис. 2). В поле зрения преобладают клетки гранулоцитарного ряда. Однако здесь, в участках вновь образованной соединительной ткани, присутствует значительное количество фибробластов. В непосредственной близости к нитям эндопротеза определяются единичные гигантские клетки инородных тел. Вокруг нитей эндопротеза в положении sublay сформирована тонковолокнистая соединительнотканная капсула, покрывающая со всех сторон нити эндопротеза и отграничивающая его от окружающей рыхлой предбрюшинной клетчатки. Визуально толщина капсулы практически во всех наблюдениях значительно меньше, чем в серии с имплантацией эндопротеза в положении onlay. Во внутреннем слое капсулы сохраняются участки клеточной инфильтрации, 
где наряду с клетками воспалительного инфильтрата отмечается значительное количество свободных клеток стромы (фибробластов и фиброци- тов). Около нитей эндопротеза определяются единичные гигантские клетки инородных тел (рис. 3).



Рис. 1. Патоморфологические изменения в тканях брюшной стенки на 30-е сутки эксперимента (onlay): волокнистая соединительнотканная капсула вокруг эндопротеза. Окр.: Ван Гизон, ув. х100.

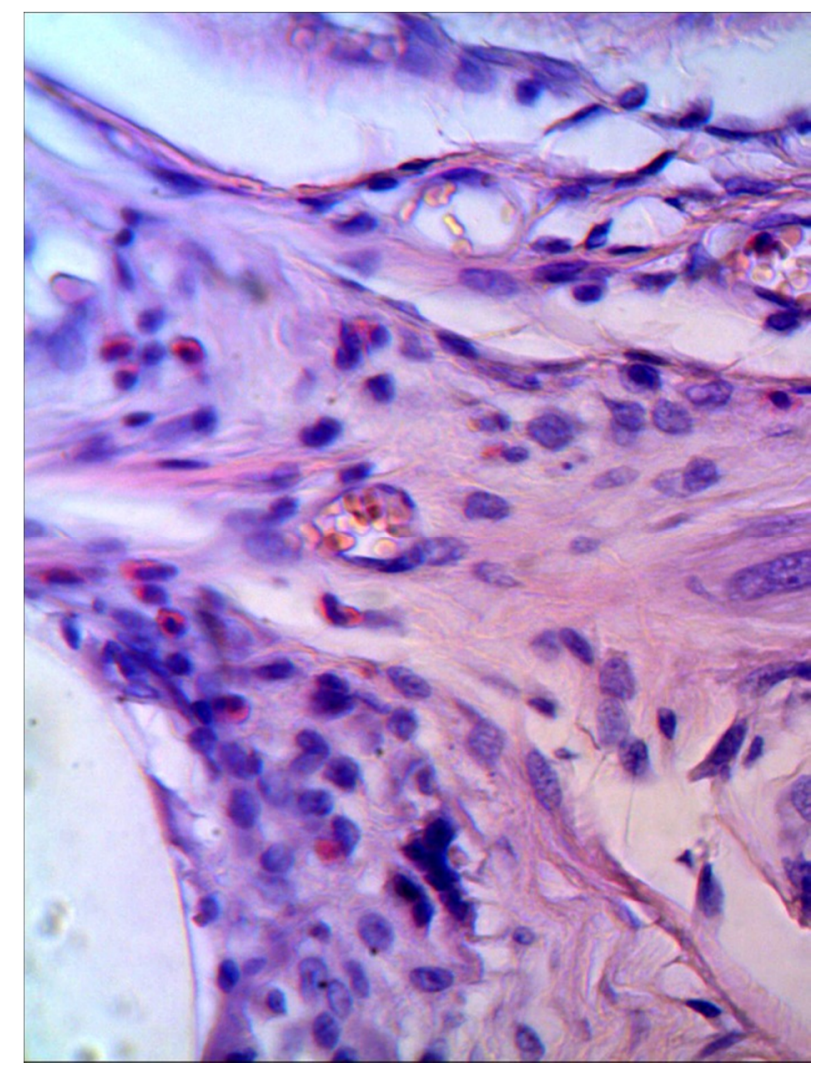

Рис. 2. Патоморфологические изменения в тканях брюшной стенки на 30-е сутки эксперимента (onlay): круглоклеточная инфильтрация внутреннего отдела капсулы. Окр.: Г-Э, ув. х400. 


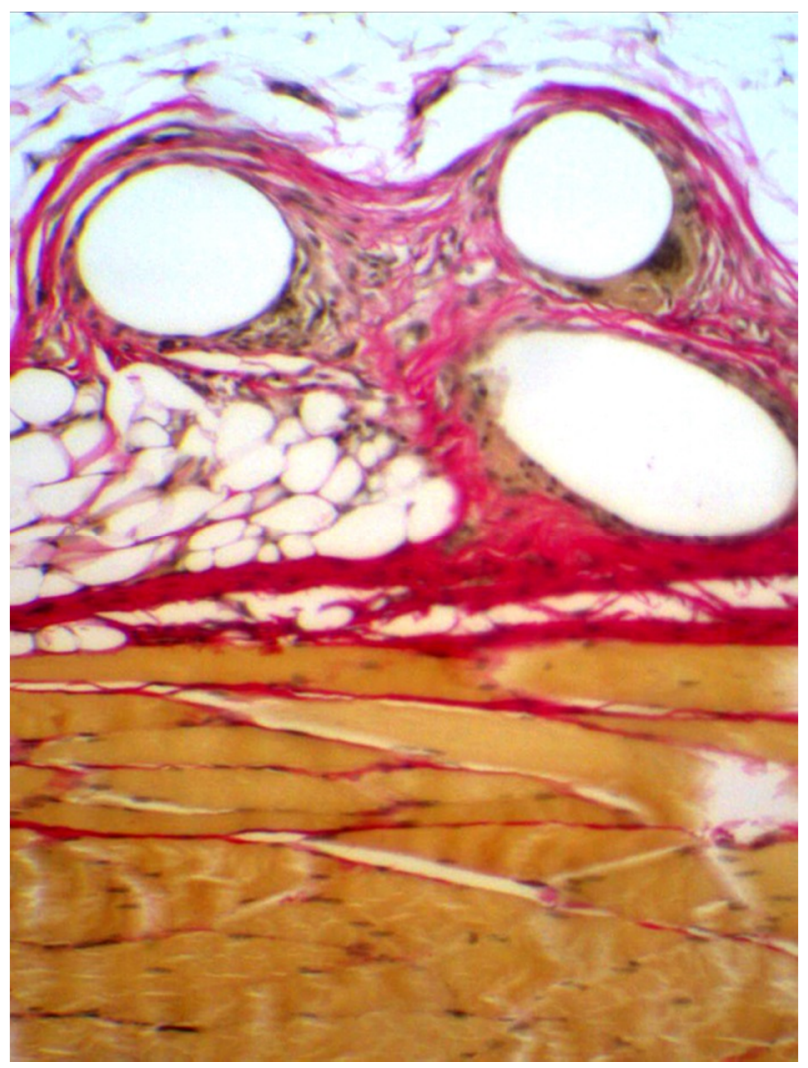

Рис. 3. Патоморфологические изменения в тканях брюшной стенки на 30 -е сутки эксперимента (sublay): тонковолокнистая соединительнотканная капсула, покрывающая со всех сторон нити эндопротеза. Окр.: Ван Гизон, ув. х100.

На 60-е сутки вокруг нитей эндопротеза в положении onlay располагается оформленная волокнистая соединительнотканная капсула. Наружный слой капсулы состоит из толстых коллагеновых волокон, среди клеток наружного слоя преобладают зрелые фиброциты. Внутренний слой капсулы помимо тонких коллагеновых волокон, окружающих нити сетки, содержит участки молодой соединительной ткани с явлениями инфильтрации лимфоцитами, макрофагами и моноцитами. Здесь же определяется большое количество фибробластов, имеются единичные гигантские клетки инородных тел. Вокруг нитей эндопротеза в положении sublay сформирована соединительнотканная капсула, состоящая из тонких коллагеновых волокон. Вокруг сетки сохраняется умеренная инфильтрация лимфоцитами и макрофагами. Здесь же определяется большое количество фибробластов и фиброцитов. Имеются единичные гигантские клетки.

На 90-е сутки вокруг нитей эндопротеза в положении onlay определяется выраженная волокнистая соединительнотканная капсула, плотно окружающая сетку и без видимых границ переходящая в окружающую грубую волокнистую соединительную ткань. Внутри около нитей сетки сохраняется умеренная инфильтрация лимфоцитами, макрофагами и моноцитами. Здесь же име- ются единичные гигантские клетки инородных тел. На 90-е сутки эндопротез в положении sublay окружен оформленной соединительной тканью. Как и на предыдущих сроках, волокна капсулы тонкие. Около нитей встречаются участки незрелой соединительной ткани со слабовыраженной инфильтрацией лимфоцитами и макрофагами. Здесь среди других клеток определяется большое количество фибробластов и фиброцитов. Имеются единичные гигантские клетки инородных тел.

На 180-е сутки вокруг нитей эндопротеза в положении onlay определяется грубая оформленная соединительная ткань, представленная волокнами, расположенными концентрически вокруг нитей эндопротеза и клеточными элементами, преимущественно фиброцитами. Непосредственно возле нитей сохраняется умеренная инфильтрация макрофагами и лимфоцитами (рис. 4). Вокруг нитей эндопротеза в положении sublay на этом сроке гистологическая картина аналогичная (рис. 5). Так же как и в положении onlay, непосредственно возле нитей сохраняются участки молодой соединительной ткани с явлениями слабой инфильтрации макрофагами и лимфоцитами. В промежутках между нитями эндопротеза новообразованная соединительная ткань не определяется, воспалительные явления отсутствуют. 


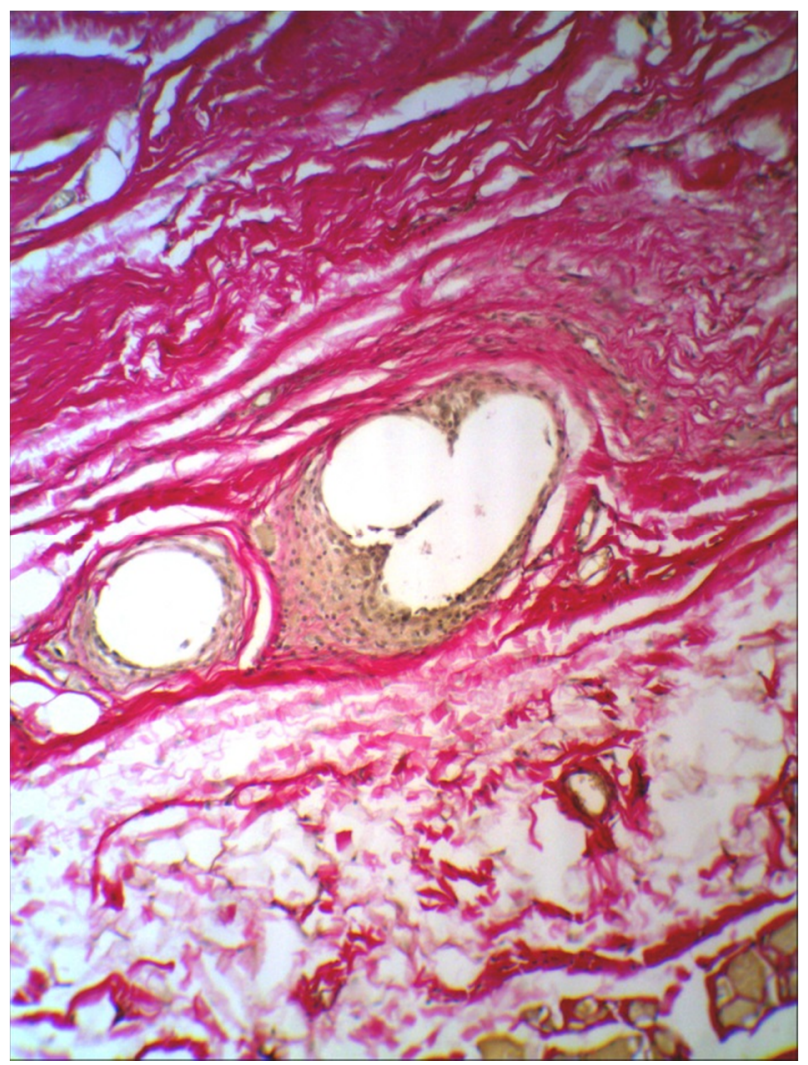

Рис. 4. Патоморфологические изменения в тканях брюшной стенки на 180 -е сутки эксперимента (onlay): грубая оформленная соединительная ткань вокруг нитей эндопротезов. Окр.: Ван Гизон, ув. х100.



Рис. 5. Патоморфологические изменения в тканях брюшной стенки на 180-е сутки эксперимента (sublay): то же. Окр.: Ван Гизон, ув. х100. 
Гистологические исследования подтвердили результаты морфологических исследований соединительнотканных капсул, сформированных вокруг имплантированных протезов. Соединительнотканная капсула на ранних сроках эксперимента (до 60-х суток) при надапоневротической имплантации протеза сопровождается более выраженной круглоклеточной воспалительной инфильтрацией, которая, как известно, являясь признаком хронических воспалительных процессов в тканях, приводит к развитию фиброзных и склеротических изменений. Однако на поздних сроках эксперимента (180-е сутки) различий в гистологической картине соединительнотканных капсул вокруг протеза при различных вариантах его расположения нет. Это может быть результатом завершения ремоделирования соединительной ткани и окончательной интеграции эндопротезов в брюшную стенку.

Таким образом, имплантация легкого усиленного эндопротеза в положении onlay, в сравнении с его с положением sublay, сопровождается более выраженной воспалительной инфильтрацией на ранних (до 60-х суток) сроках эксперимента. На поздних сроках (180-е сутки) репаративная реакция тканей на имплантацию обоих материалов не зависит от варианта расположения протеза. Следовательно, выбор способа размещения протезов должен определяться индивидуально у каждого больного на основании оценки тяжести его состояния, выраженности склеротических изменений тканей в области грыжевых ворот, квалификации хирурга, наличия или отсутствия воспалительного процесса в брюшной полости. В экстренной хирургии при лечении больных с ущемленными вентральными грыжами целесообразно размещать протез надапоневротически, как более простой способ в техническом исполнении. Во время плановых абдоминальных операций при отсутствии выраженных склеротических изменений тканей брюшной стенки, препятствующих их разделению, высокой квалификации оперирующего хирурга следует применять подапоневротический вариант расположения протеза.

\section{ЛИТЕРАТУРА / REFERENCES}

1. Алекберзаде А.В., Липницкий Е.М., Сундуков И.В. Открытая аллопластика послеоперационных вентральных грыж // Хирургия. Журнал им. Н.И. Пирогова. - 2011. - № 4. - С. 13-16. [Alekberzade A.V., Lipnitskiy E.M., Sundukov I.V. Open alloplasty of postoperative ventral hernias. Khirurgiya. Zhurnal im. N.I. Pirogova. 2011; (4): 13-16. (in Russ.)].

2. Ануров М.В., Титкова С.М., Эттингер А.П. Сравнение результатов пластики грыжевого дефекта стандартными и легкими сетчатыми эндопротеза- ми с одинаковым трикотажным переплетением // Бюллетень экспериментальной биологии и медицины. - 2010. - Т. 150, № 10. - С. 433-439. [Аnиrov M.V., Titkova S.M., Ettinger A.P. Comparison of the results of hernia defect plasty with standard and light mesh endoprostheses with the same knitted weave. Byulleten' eksperimental'noy biologii i meditsiny. 2010; 150 (10): 433-439 (in Russ.)].

3. Мошкова Т.А., Васильев С.В., Олейник В.В., Морозов А.Б. Оценка способов размещения полипропиленовых сеток при аллопластике вентральных грыж // Вестник хирургии им. И.И. Грекова. 2007. - T. 166, № 2. - C. 78-81. [Moshkova T.A., Vasiliev S.V., Olejnik V.V., Morozov A.V. Assessment of methods of placement of polypropylene meshes in alloplasty of ventral hernias. Vestnik khirurgii im. I.I. Grekova. 2007; 166 (2): 78-81 (in Russ.)].

4. Нетяга А.А., Парфенов А.О., Нутфуллина Г.М., Жуковский B.A. Легкие или композитные эндопротезы для герниопластики: выбор материала на основании экспериментального изучения их биосовместимых свойств // Современные проблемы науки и образования. - 2013. - № 5. - С. 370. Режим доступа: http:/www.scienceeducation.ru/ru/article/view?id=10712, свободный (05.08.2017) [Netyaga A.A., Parfenov A.O., Nutfullina G.M., Zhukovsky V.A. Comparative experimental study of the biomechanical properties of the standard, light and composite meshes for abdominal wall after implantation. Sovremennye problemy nauki i obrazovaniya. 2013; (5): 370. Access mode: http://www.science-

education.ru/ru/article/view?id=10712, $\quad$ free (05/08/2017) (in Russ.)].

5. Тимошин А.Д., Шестаков А.Л., Загорулько О.И., Инаков А.Г. Оценка функции мышц передней брюшной стенки после герниопластики // Бюллетень сибирской медицины. - 2007. - Т. 6, № 3. C. 62-64. [Timoshin A.D., Shestakov A.L., Zagorulko O.I., Inakov A.G. Abdominal wall muscles function estimation after hernioplasty. Byulleten' sibirskoy meditsiny. 2007; 6 (3): 62-64. (in Russ.)].

6. Титов В.В., Калачев И.И., Тимошин А.Д. Сравнительная оценка под- и надапоневротнческой пластики передней брюшной стенки у больных с послеоперационными вентральными грыжами // Анналы хирургии. - 2008. - № 4. - С. 56-59. [Titov V.V., Kalachev I.I., Timoshin A.D. Comparative analysis of abdominal subaponeurotic and supraaponeurotic plasty in patients with postoperative ventral hernias. Annaly khirurgii. 2008; (4): 56-59. (in Russ.)].

7. Цверов И.А., Базаев А.В. Оценка основных способов аллопластики с целью оптимизации лечения больных с послеоперационными вентральными грыжами // Современные технологии в медицине. - 2011. - № 2. - С. 73-76. [Tsverov I.A., Bazaev A.V. The assessment of main alloplasty techniques in order to optimize the treatment of patients with postoperative ventral hernias. Sovremennye tekhnologii v meditsine. 2011; (2): 73-76. (in Russ.)].

8. Klinge U., Klosterhalfen B. Modified classification of surgical meshes for hernia repair based on the anal- 
yses of 1,000 explanted meshes // Hernia. - 2012. Vol. 16, N 3. - P. 251-258.

9. Lintin L.A., Kingsnorth A.N. Mechanical failure of a lightweight polypropylene mesh // Hernia. - 2014. Vol. 18, N 1. - P. 131-133.

10. Petro C.C., Nahabet E.H., Criss C.N., Orenstein S.B., Von Recum H.A., Novitsky Y.W., Rosen M.J. Central failures of lightweight monofilament polyester mesh causing hernia recurrence: a cautionary note // Hernia. - 2015. - Vol. 19, N 1. - P. 155-159.

11. Zuvela M., Galun D., Djuric-Stefanovic A., Palibrk I., Petrovic M., Milicevic M. Central rupture and bulging of low-weight polypropylene mesh following recurrent incisional sublay hernioplasty // Hernia. - 2014. Vol. 18, N 1. - P. 135-140. 